\title{
Assessment of knowledge levels of women farmers in the areas of nutrition and health care
}

\author{
L. Uma Devi, Bilquis and K. Sudha Rani
}

Received: 01.12.2019; Revised: 25.03.2020; Accepted: 10.05.2020

See end of the paper for authors' affiliations

L. Uma Devi

College of Community Science,

Acharya N.G. Ranga Agricultural

University, Lam, Guntur

(A.P.)India

Email : lingareddy.umadevi@

gmail.com
ABSTRACT : The study aimed at determining the existing knowledge levels of thirty women farmers in the areas of nutrition and health care of infants and pre school children. A semi structured questionnaire was used to collect the socio demographic data, knowledge, attitude and practices about nutrition and health care during pregnancy. Pre-Post knowledge assessment was done to study the impact of intervention programme. The results revealed that women farmers had poor knowledge of nutritional aspects like balanced diet, protein rich foods, low cost iron foods etc during pre test. After implementing intervention programme to the rural mothers for a period of six months a significant improvement in the knowledge was observed during post-test. Rural mothers had good knowledge on health aspects like immunization, health check-ups during prenatal and post natal periods. The above findings can be used to plan a customized nutritional intervention programme aiming to improve the maternal nutritional knowledge and practices and eventually improve the health status of the pregnant mothers especially in rural areas.

KEY WORDS: Nutrition, Rural mothers, Intervention

- HOW TO CITE THIS PAPER : Devi, L. Uma, Bilquis and Rani, K. Sudha (2020). Assessment of knowledge levels of women farmers in the areas of nutrition and health care. Asian J. Home Sci., 15 (1) : 120124, DOI: 10.15740/HAS/AJHS/15.1/120-124. Copyright@ 2020: Hind Agri-Horticultural Society. 